\title{
Tribological Properties of Friction Materials Developed from Non- Asbestos Materials using Response Surface Methodology
}

\author{
Abutu Joseph, Lawal Sunday Albert, Ndaliman Mohammed Baba, Lafia-Araga Ruth Anayimi \\ and Oluleye Atinuke Modupe
}

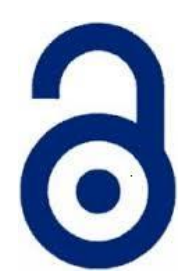

\author{
Received: 22 April 2020 \\ Accepted: 09 May 2020 \\ Published: 30 June 2020 \\ Publisher: Deer Hill Publications \\ (c) 2020 The Author(s) \\ Creative Commons: CC BY 4.0
}

\begin{abstract}
Over many years, asbestos has been used as reinforcement material in the production of brake pads production but it has lost favour due to its carcinogenic nature, as a result, there is need to investigate other possible substitute which can offer similar tribological properties as the carcinogenic material (asbestos). Several works has been carried out using different reinforcement material with the aim of finding a possible replacement for asbestos. In this work, Rule of mixture (ROM) was ustlised for sample formulation and the tribological properties of natural based material (coconut shell and seashell) were investigated using experimental design (response surface methodology) and multiresponse optimisation technique (Grey relational analysis). The multi-response performance of the formulated brake pads samples was compared with a commercial brake pad sample. The research findings revealed that sample can be produced using 52\% reinforcement, 35\% binder, $8 \%$ abrasive and 5\% friction modifier while the Grey relational analysis (GRA) showed that optimum multi-response performance of the developed coconut shell based sample can be achieved using MP, MT and CT and HTT of $12 \mathrm{MPa}, 100{ }^{\circ} \mathrm{C}, 6 \mathrm{mins}$ and $2 \mathrm{hrs}$ respectively while that of the developed seashell based brake pad can be achieved using MP, MT and CT and HTT of $10 \mathrm{MPa}, 160{ }^{\circ} \mathrm{C}, 12 \mathrm{mins}$ and $2 \mathrm{hrs}$ respectively. Also, the Analysis of variance (ANOVA) results show a percentage error of less than $5 \%$ indicating minima noise effect. In addition, the optimized coconut shell-based brake pads falls within the category of class $\mathrm{H}(\mu$ $>0.55)$ type of brake pads while seashell based sample falls within the class $G(\mu: 0.45-0.55)$ type of brake pads. It therefore concluded that the use of coconut shell can serve as a better substitute for asbestos-based brake pads.
\end{abstract}

Keywords: Brake pad, Response surface methodology, tribological properties, Grey relational analysis.

\section{INTRODUCTION}

Friction materials are materials used for the development of automobile parts such as clutch and brake pads which are utilised in the transmission and braking of various machineries like cars, aircraft, motorcycles and other automobile systems. The constituents kept varying with the aim of meeting up with environmental technology and emerging. Blau (2001) reported that friction materials can be classified as semi-metallic, organic and carbon-based, depending on the elemental composition. Mechanics working on automobile are in most cases exposed to asbestos dust in several ways. This include, grinding of friction brake or clutch, repair work on brakes and clutch, where accumulated dusts are always wiped off before the old ones are replaced using brush (Abutu et al., 2018). All these methods are capable of causing asbestos particles to become airborne which is very hazardous to the environment. Dagwa and Ibhadode (2008) reported that if old brake pads are still hard enough to be applied, automobile mechanics working on them often utilize a bench grinder to normalize the surface, or dissolve the dirts of the lining which often lead to the release of the particles of asbestos, thereby putting human at risk of contacting diseases such as pleural, peritoneal or pericardial mesothelioma, asbestos related cancer and asbestosis (Norton, 2001). Also, Mutlu et al. (2009) reported that tribological properties are very important properties in the performance of brake pads and a relatively high friction coefficient in the range of 0.3-0.7 and lower wear rate is normally desirable when using brake lining materials. Several works have been carried out with the aim of replacing asbestos as inclusion in brake pads production.

\footnotetext{
Abutu, J.1, Lawal, S. A. ${ }^{2}$, Ndaliman, M. B. ${ }^{2}$ 区, Lafia-Araga, R. A. ${ }^{3}$, Oluleye M.A. ${ }^{4}$

'Department of Mechanical Engineering, Taraba State University, Jalingo, Taraba State, Nigeria 2Department of Mechanical Engineering, Federal University of Technology, Minna, Niger State, Nigeria ${ }^{3}$ Department of Chemistry, Federal University of Technology, Minna, Niger State, Nigeria ${ }^{4}$ Department of Mechanical Engineering, Ekiti State University, Ado-Ekiti, Ekiti State, Nigeria E-mail: mbndaliman@futminna.edu.ng
}

Reference: Abutu, J., Lawal, S. A. Ndaliman, M. B., Lafia-Araga, R. A. and Oluleye,M. A. Tribological Properties of Friction Materials Developed from Non- Asbestos Materials using Response Surface Methodology. International Journal of Engineering Materials and Manufacture, 5(2), 40-49. 
Gabriel (2016) utilized periwinkle/palm shell as reinforcement material using Taguchi experimental design and reported that optimal performance of the developed friction material can be obtained using moulding pressure (140 $\mathrm{KPa}$ ), moulding temperature $\left(150{ }^{\circ} \mathrm{C}\right)$ and curing time (10 minutes) as process parameter. Also, Abutu et al. (2018) with the aim of finding a substitute for asbestos developed a friction material using seashell as reinforcement material and utilizing response surface-central composite design (RSM-CCD) technique and grey relational analysis (GRA). The authors reported that seashell can serve as good substitute for asbestos in friction material production and that multiresponse performance of the developed material can be obtained using 1 hour heat treatment time, 12 minutes curing time, $160^{\circ} \mathrm{C}$ moulding temperature and $14 \mathrm{MPa}$ moulding pressure. Also Ruzaidi et al. (2011) formulated a nonasbestos containing brake pad with varying composition of Polychlorinated Biphenyls (PCB) and palm ash waste along with thermoset resin as a binder and metal filler as abrasive. Five samples were produced using moulding pressure, moulding temperature and curing time of $122 \mathrm{MPa}, 150{ }^{\circ} \mathrm{C}$ and 5 minutes respectively and were tested to examine its compression strength, water absorption rate, wear rate, and morphological properties. Experimental findings indicated that the optimum performance (mechanical and wear properties) of the brake pads was obtained using higher percentage of palm ash and also, wear properties of the developed brake pads compared satisfactorily with conventional brake pad. Also, Mutlu et al. (2009) with the aim of finding a possible replacement for asbestos whose dust is hazardous developed friction materials using Rice Husk Dust (RHD) and Rice Straw Dust (RSD) to study the tribological behaviour of brake pads. The materials in each brake pad were composed of RHD, RSD, copper particles, barite, brass, cashew, steel fibres, graphite and alumina. The newly formulated brake pads were tested in order to study their tribological performance and the results revealed a mean friction coefficient of $0.315-0.381$ which is very low to be applied in heavy duty automobiles brake pads as specified in the work of Dagwa and Ibhadode (2008) while the wear rate varies from $0.000853-0.001041 \mathrm{~g} / \mathrm{mm}^{2}$.

In addition, Fono-Tamo and Koya, (2011), also developed friction materials using palm kernel shell combined with other materials and observed that the optimal mechanical properties of the developed material showed a hardness of 32.34 and shear strength of $40.95 \mathrm{MPa}$ while the optimum coefficient of friction of was found to be 0.43 . Also, Ikpambese et al. (2014) developed an asbestos-free friction material using palm kernel fibres as reinforcement material and reported that sample with 10\% palm kernel fiber, 6\% Al2O3, 40\% epoxy-resin, 29\% graphite gave and $15 \%$ calcium carbonate gave the optimum performance. Similarly, Bashar et al. (2012) utilized coconut shell powder as reinforcement material to develop friction material and found that high inclusion of coconut powder may results in brittleness of the composite and also samples with $60 \%$ matrix and $10 \%$ reinforcement as well as $50 \%$ matrix and $10 \%$ reinforcement can be utilized in the production of friction materials. Yawas et al. (2016) also developed an asbestos-free friction material using periwinkle shell as reinforcement material and revealed that optimal periwinkle shell reinforced sample produced using sieve size of $125 \mu \mathrm{m}$ possessed specific gravity $(1.01 \mathrm{~g} / \mathrm{cm} 3)$, coefficient of friction (0.41), hardness (116.7 HRB), compressive strength (147 N/mm2), and thickness swell in water $(0.39 \%)$ and thickness swell in SEA oil (0.37\%). Also, Ibhadode and Dagwa, (2008) used palm kernel shell (PKS) as reinforcement material along with other constituents in the production of friction materials and found that optimal sample produced using $56 \%$ reinforcement, $24 \%$ binder, $14 \%$ abrasives and $6 \%$ friction modifier compared favourably with commercial samples as a result can served as replacement for asbestos in friction lining production. Therefore, in this study, locally sourced coconut shell and seashell were separately used as reinforcement material along with other constituents to develop an environmentally friendly brake pad samples using Central composite design (CCD)-Response surface methodology (RSM) experimental design technique. The multi-response performance of the two brake pad samples was compared with commercially available brake pad by examining their tribological properties (wear rate and friction coefficient).

\section{MATERIALS AND METHODS}

\subsection{Materials}

Coconut shells (Figure 1a) were sourced locally from a local coconut trader in Sabon Tasha market, Kaduna - Nigeria, seashells (Figure 1b) were collected from a local seafood vendor in Lagos bar beach, Lagos-Nigeria. Also, alumina and commercial brake sample (Figure 1c) designed for Mazda 323 and produced by lbeto Group of Companies were sourced from a commercial shop situated in Kaduna-Nigeria while epoxy resin used together with hardener (Sikadur 42T) were purchased from a chemical store located in Onitsha-Nigeria while graphite (Figure 1d) sourced from dry cell batteries (1.5 volt, TIGER).

\subsection{Method}

Development of brake pads constitute the preparation of sourced materials, experimental design using Minitab 17 software, compression moulding process, testing of developed samples and analysis of experimental results using signal to noise ( $\mathrm{S} / \mathrm{N})$, analysis of variance (ANOVA) and Grey relational analysis (GRA).

\subsubsection{Materials preparation}

Materials preparation involved the preparation of the coconut shells, seashells and graphite powder. These involved washing, cleaning using tissue paper, drying under the sun for 24 hours followed by crushing with metallic mortar and pestle and thereafter, grinding using grinding machine situated at Samaru, Zaria and then sieving using a sieve size of $10 \mu \mathrm{m}$. 


\subsubsection{Design of Experiment using RSM Design Technique}

In this study, CCD via RSM experimental design consisting of moulding pressure (MP), moulding temperature (MT), curing time $(C T)$ and heat treatment $(\mathrm{HTT})$ was built in accordance to standard $\mathrm{L}_{27}(2)^{4}$ using Minitab 17 statistical software. The factor levels of process parameters and experimental design matrix are shown in Table 1 and 2 respectively.
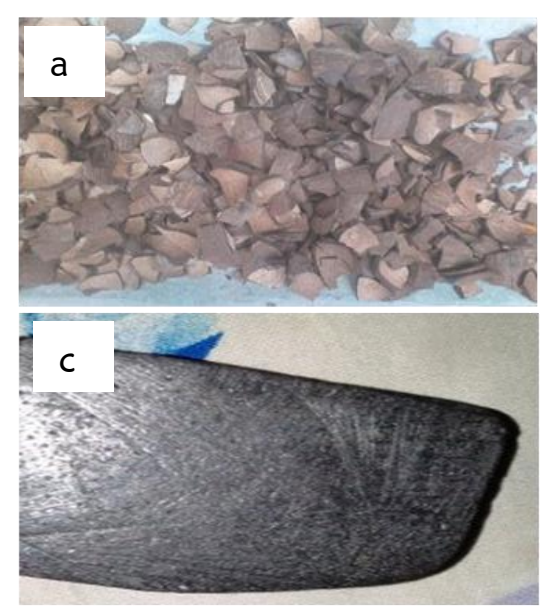
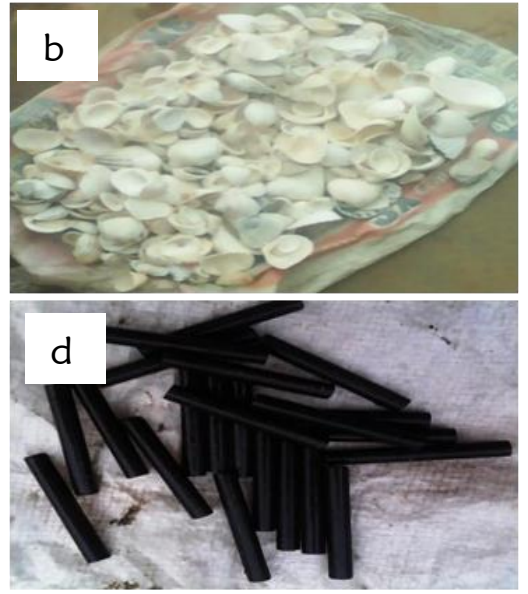

Figure 1: Reinforcement and friction modifier used (a) crushed coconut shells (b) seashells (c) commercial brake pad sample (d) extracted graphite rods

Table 1: Factor level of process parameters

\begin{tabular}{|c|c|c|c|c|}
\hline Factor & $\mathrm{MP}(\mathrm{MPa})$ & $\mathrm{MT}\left({ }^{\circ} \mathrm{C}\right)$ & $C T(\min )$ & HTT (hr) \\
\hline High & 16 & 160 & 10 & 4 \\
\hline Low & 12 & 120 & 6 & 2 \\
\hline & \multicolumn{3}{|c|}{ Table 2: RSM-CCD experimental design matrix } & \\
\hline Run & MT (०C) & $\mathrm{MP}(\mathrm{MPa})$ & CT (minute) & HTT (hour) \\
\hline 1 & 120 & 12 & 6 & 2 \\
\hline 2 & 120 & 16 & 6 & 2 \\
\hline 3 & 160 & 12 & 6 & 2 \\
\hline 4 & 160 & 16 & 6 & 2 \\
\hline 5 & 120 & 12 & 10 & 2 \\
\hline 6 & 120 & 16 & 10 & 2 \\
\hline 7 & 160 & 12 & 10 & 2 \\
\hline 8 & 160 & 16 & 10 & 2 \\
\hline 9 & 120 & 12 & 6 & 4 \\
\hline 10 & 120 & 16 & 6 & 4 \\
\hline 11 & 160 & 12 & 6 & 4 \\
\hline 12 & 160 & 16 & 6 & 4 \\
\hline 13 & 120 & 12 & 10 & 4 \\
\hline 14 & 120 & 16 & 10 & 4 \\
\hline 15 & 160 & 12 & 10 & 4 \\
\hline 16 & 160 & 16 & 10 & 4 \\
\hline 17 & 140 & 10 & 8 & 3 \\
\hline 18 & 140 & 18 & 8 & 3 \\
\hline 19 & 100 & 14 & 8 & 3 \\
\hline 20 & 180 & 14 & 8 & 3 \\
\hline 21 & 140 & 14 & 4 & 3 \\
\hline 22 & 140 & 14 & 12 & 3 \\
\hline 23 & 140 & 14 & 8 & 1 \\
\hline 24 & 140 & 14 & 8 & 5 \\
\hline 25 & 140 & 14 & 8 & 3 \\
\hline 26 & 140 & 14 & 8 & 3 \\
\hline 27 & 140 & 14 & 8 & 3 \\
\hline
\end{tabular}




\subsubsection{Samples Formulation and Production}

Sample formulation was carried out using Rule of mixture (ROM) technique outlined in the work of Askeland (1985) utilising density $(\rho)$ as a criteria while production was carried out on a compression moulding machine situated at Federal College of Chemical and Leather Technology (FCCLT), Samaru, Zaria (Polymer workshop) and was conducted using the procedure adopted by Abutu et al. (2019) which involved utilising varying process parameters shown in Table 2 with constant percentage composition as obtained from ROM. This procedure further involved pouring and mixing epoxy resin and hardener (catalyst) in the ratio of 2:1 in a separate container, followed by filling of mould cavity with total mixture of mixed binder and filler materials, then, the withdrawal of cured samples from the moulding machine, cooling of samples and removal of the cooled samples from the mould.

\subsubsection{Sample Characterization}

Tribological properties (wear rate and friction coefficient) of the developed and commercial samples were evaluated using a Tribometer (ANTON PAAR GmbH, CSM Instrument, Strasse 20, 8054 Graz-Austria) and experiment was conducted in accordance with ASTM G99 testing procedure using the test conditions presented in Table 3.

\section{RESULTS AND DISCUSSION}

\subsection{Samples formulation and Production}

The results of sample formulation indicate that samples should be produced using $52 \%$ reinforcement material (seashell or coconut shell), 35\% binder (epoxy resin and hardener), $8 \%$ abrasive (Alumina) and 5\% friction modifier (graphite).

\subsection{Experimental Results}

The average values of experimental result along with the individual signal-to noise $(\mathrm{S} / \mathrm{N})$ ratios for wear rate $(\mathrm{Wr})$ and friction coefficient $(\mu)$ of the developed brake pad samples are shown in Table 4. S/N ratios of friction coefficient were calculated using larger-the better (Eqn. 1) while that of wear rate was calculated using smaller-the better (Eqn. 2).

$$
\begin{aligned}
& S / N=-10 \log \frac{1}{N}\left(\sum_{N=1}^{N} \frac{1}{r^{2}}\right) \\
& S / N=-10 \log \frac{1}{N}\left(\sum_{N=1}^{N} r^{2}\right)
\end{aligned}
$$

$r=$ response value of given factor level combination,

$\mathrm{N}=$ number of factor level combination

From the experimental results presented in Table 4, it can be observed that the values of the friction coefficient varied from 0.477 to 0.788 for coconut shell-based samples and 0.43 to 0.61 for seashell-based samples. These values falls within the class $\mathrm{F}(0.35-0.45), \mathrm{G}(0.45-0.55)$ and $\mathrm{H}(>0.55)$ type of brake pads recommended for use in automobile by Society of Automobile Engineers (SAE) and reported by Blau (2001) as well as Dagwa and Ibhadode (2006). These results are in good agreement with the earlier work of Roubicek et al. (2008) who reported that friction coefficient that falls within the range of $0.30-0.70$ is desirable in brake pads. Therefore, seashell and coconut shellbased brake pads are suitable for use in automobiles.

\subsection{Multi-response optimisation}

Multi-response optimisation of experimental results was carried using Grey relational analysis (GRA) technique. This technique was adopted to investigate the optimal process parameters that will produce the multi-response performance of the coconut and seashell-based brake pads. The procedure for GRA include using the values of $S / N$ ratios shown in Table 3 to calculate the Grey relational grade (GRG) for friction coefficient and wear rate using larger the better (Eqn. 3) and smaller the better (Eqn. 4) attribute respectively. This is followed by the calculation of Grey relational coefficient (GRC) using Eqn. 5 and finally, the calculation using Grey relational grade using Eqn. 6.

Larger-the-better attributes $\left(\mathrm{w}_{\mathrm{ij}}\right)=\frac{a_{i j}-\underline{a_{i}}}{\overline{a_{i}}-a_{j}}$

Smaller-the-better attributes $\left(\mathrm{w}_{\mathrm{ij}}\right)=\frac{\bar{a}_{i j}-a_{i j}}{\overline{a_{j}}-\underline{a}_{j}}$

Where, $\mathrm{a}_{\mathrm{i}}=$ the performance value of alternative $\mathrm{i}$ attribute $\mathrm{j}$ and $\overline{a_{j}}=\max \left\{\mathrm{a}_{\mathrm{ij}}, \mathrm{i}=1,2, \ldots, \mathrm{x}\right\}$.response and $a_{j}$ $=\min \left\{l_{i j}, i=1,2, \ldots, x\right\}$.

$$
\operatorname{GRC},\left(x_{0 j}, x_{i j}\right)=\frac{D_{\min }+\lambda D_{\max }}{D_{i j}+\lambda D_{\max }}
$$


$\mathrm{j}=1,2, \ldots, 27$ and $\mathrm{i}=1,2, \ldots, 27, \mathrm{D}=\mathrm{x}_{0 j}-x_{i j},,=\min \left(\mathrm{Dij}_{\mathrm{ij}} \mathrm{i}=1,2, \ldots, \mathrm{x} ; \mathrm{j}=1,2, \ldots, \mathrm{y}\right), D_{\operatorname{nax}}$ and $D_{\min }$ $=$ maximum and minimum GRG value for response and $\lambda$ is the distinguishing coefficient, $\lambda \in(0,1)$. The aim of distinguishing coefficient is to reduce or increase the range of the grey relational coefficient and 0.5 is the widely accepted value (Chin, 2003).

$$
\text { Grade }=\frac{\sum G R C}{\text { No.of responses }}
$$

The results of GRG, GRC and grades obtained from GRA are presented in Table 5 and the resulting factor effects of process parameters are shown in Table 6 while the main effect plots for coconut shell and seashell based brake pads are shown in Figure 2 and 3 respectively.

Table 3: Test parameters/conditions for tribology test

\begin{tabular}{ll}
\hline Ball Diameter & $10 \mathrm{~mm}$ \\
Speed & $10 \mathrm{~cm} / \mathrm{s}$ \\
Load & $7 \mathrm{~N}$ \\
Ball Material & Stainless Steel \\
Duration of Test & 223 seconds \\
Humidity of environment & $55 \%$ \\
Temperature of environment & $25{ }^{\circ} \mathrm{C}$ \\
\hline
\end{tabular}

Table 4: Experimental results and $S / \mathrm{N}$ ratios of developed samples

\begin{tabular}{|c|c|c|c|c|c|c|c|c|c|c|c|c|}
\hline \multirow[t]{2}{*}{ Run } & \multirow{2}{*}{$\begin{array}{c}\mathrm{MP} \\
(\mathrm{MPa})\end{array}$} & \multirow{2}{*}{$\begin{array}{l}\text { MT } \\
\left({ }^{\circ} \mathrm{C}\right)\end{array}$} & \multirow{2}{*}{$\begin{array}{c}\mathrm{CT} \\
(\mathrm{min})\end{array}$} & \multirow{2}{*}{$\begin{array}{c}\mathrm{HT} \\
\mathrm{T} \\
(\mathrm{hr})\end{array}$} & \multicolumn{4}{|c|}{ Coconut shell based } & \multicolumn{4}{|c|}{ Seashell based } \\
\hline & & & & & $\mu$ & $\begin{array}{c}\mu \\
(\mathrm{dB}) \\
\end{array}$ & $\begin{array}{c}W r \\
(m g / m)\end{array}$ & $\begin{array}{c}W r \\
(\mathrm{~dB})\end{array}$ & $\mu$ & $\begin{array}{c}\mu \\
(\mathrm{dB}) \\
\end{array}$ & $\begin{array}{c}\begin{array}{c}W r \\
(m g / m)\end{array} \\
\end{array}$ & $\begin{array}{c}W r \\
(\mathrm{~dB})\end{array}$ \\
\hline 1 & 12 & 120 & 6 & 2 & 0.788 & -2.07 & 0.2620 & 11.64 & 0.492 & -6.16 & 0.3340 & 9.525 \\
\hline 2 & 16 & 120 & 6 & 2 & 0.652 & -3.72 & 1.0936 & -0.78 & 0.447 & -6.99 & 0.2685 & 11.42 \\
\hline 3 & 12 & 160 & 6 & 2 & 0.686 & -3.27 & 0.1310 & 17.66 & 0.548 & -5.22 & 0.2358 & 12.55 \\
\hline 4 & 16 & 160 & 6 & 2 & 0.688 & -3.25 & 0.1703 & 15.38 & 0.529 & -5.53 & 0.1834 & 14.73 \\
\hline 5 & 12 & 120 & 10 & 2 & 0.685 & -3.29 & 0.2030 & 13.85 & 0.556 & -5.10 & 0.3995 & 7.970 \\
\hline 6 & 16 & 120 & 10 & 2 & 0.601 & -4.42 & 0.1244 & 18.10 & 0.525 & -5.60 & 0.3536 & 9.029 \\
\hline 7 & 12 & 160 & 10 & 2 & 0.601 & -4.42 & 0.3995 & 7.970 & 0.58 & -4.73 & 2.6130 & -8.34 \\
\hline 8 & 16 & 160 & 10 & 2 & 0.651 & -3.73 & 0.0393 & 28.11 & 0.593 & -4.54 & 0.2881 & 10.81 \\
\hline 9 & 12 & 120 & 6 & 4 & 0.566 & -4.94 & 0.6614 & 3.590 & 0.565 & -4.96 & 0.2358 & 12.55 \\
\hline 10 & 16 & 120 & 6 & 4 & 0.533 & -5.47 & 0.2161 & 13.31 & 0.572 & -4.85 & 0.1637 & 15.72 \\
\hline 11 & 12 & 160 & 6 & 4 & 0.688 & -3.25 & 0.0720 & 22.85 & 0.573 & -4.84 & 0.2554 & 11.86 \\
\hline 12 & 16 & 160 & 6 & 4 & 0.496 & -6.09 & 0.0655 & 23.68 & 0.568 & -4.91 & 0.1113 & 19.07 \\
\hline 13 & 12 & 120 & 10 & 4 & 0.558 & -5.07 & 0.6549 & 3.677 & 0.430 & -7.33 & 0.2096 & 13.57 \\
\hline 14 & 16 & 120 & 10 & 4 & 0.649 & -3.76 & 0.7138 & 2.928 & 0.610 & -4.29 & 0.2816 & 11.01 \\
\hline 15 & 12 & 160 & 10 & 4 & 0.568 & -4.91 & 0.6680 & 3.505 & 0.534 & -5.45 & 0.1899 & 14.43 \\
\hline 16 & 16 & 160 & 10 & 4 & 0.477 & -6.43 & 0.7204 & 2.849 & 0.496 & -6.09 & 0.7924 & 2.021 \\
\hline 17 & 10 & 140 & 8 & 3 & 0.668 & -3.50 & 0.1441 & 16.83 & 0.567 & -4.93 & 0.1834 & 14.73 \\
\hline 18 & 18 & 140 & 8 & 3 & 0.571 & -4.87 & 0.0720 & 22.85 & 0.546 & -5.26 & 0.4977 & 6.061 \\
\hline 19 & 14 & 100 & 8 & 3 & 0.617 & -4.19 & 0.6483 & 3.764 & 0.521 & -5.66 & 0.1244 & 18.10 \\
\hline 20 & 14 & 180 & 8 & 3 & 0.648 & -3.77 & 0.0589 & 24.59 & 0.491 & -6.18 & 0.2816 & 11.01 \\
\hline 21 & 14 & 140 & 4 & 3 & 0.650 & -3.74 & 0.0197 & 34.13 & 0.571 & -4.87 & 0.2161 & 13.31 \\
\hline 22 & 14 & 140 & 12 & 3 & 0.550 & -5.19 & 0.0786 & 22.09 & 0.544 & -5.29 & 2.1545 & -6.67 \\
\hline 23 & 14 & 140 & 8 & 1 & 0.720 & -2.85 & 0.0066 & 43.68 & 0.509 & -5.87 & 0.1048 & 19.59 \\
\hline 24 & 14 & 140 & 8 & 5 & 0.614 & -4.24 & 0.0720 & 22.85 & 0.519 & -5.70 & 0.6549 & 3.677 \\
\hline 25 & 14 & 140 & 8 & 3 & 0.503 & -5.97 & 0.7138 & 2.928 & 0.498 & -6.06 & 0.2227 & 13.05 \\
\hline 26 & 14 & 140 & 8 & 3 & 0.528 & -5.55 & 0.8382 & 1.533 & 0.511 & -5.83 & 0.2096 & 13.57 \\
\hline 27 & 14 & 140 & 8 & 3 & 0.521 & -5.66 & 0.7924 & 2.021 & 0.497 & -6.07 & 0.2030 & 13.85 \\
\hline
\end{tabular}


Table 5: Results of Grey relational analysis (GRA)

\begin{tabular}{|c|c|c|c|c|c|c|c|c|c|c|}
\hline \multirow[t]{3}{*}{ Senario } & \multicolumn{4}{|c|}{ GRG } & \multicolumn{4}{|c|}{ GRC } & \multicolumn{2}{|c|}{ Grade } \\
\hline & \multicolumn{2}{|c|}{ Coconut shell based } & \multicolumn{2}{|c|}{ Seashell based } & \multicolumn{2}{|c|}{$\begin{array}{c}\text { Coconut shell } \\
\text { based }\end{array}$} & \multicolumn{2}{|c|}{ Seashell based } & \multirow{2}{*}{$\begin{array}{c}\text { Coconu } \\
t \text { shell } \\
\text { based }\end{array}$} & \multirow[t]{2}{*}{$\begin{array}{c}\text { Seashell } \\
\text { based }\end{array}$} \\
\hline & $\mu$ & $W_{r}$ & $\mu$ & $W_{r}$ & $\mu$ & $W_{r}$ & $\mu$ & $W_{r}$ & & \\
\hline$x_{\circ}$ & 1.00 & 1.00 & 1.00 & 1.00 & - & - & - & - & - & - \\
\hline 1 & 1.00 & 0.72 & 0.39 & 0.36 & 1.00 & 0.64 & 0.45 & 0.44 & 0.82 & 0.45 \\
\hline 2 & 0.62 & 1.00 & 0.11 & 0.29 & 0.57 & 1.00 & 0.36 & 0.41 & 0.79 & 0.39 \\
\hline 3 & 0.72 & 0.59 & 0.69 & 0.25 & 0.64 & 0.55 & 0.62 & 0.40 & 0.60 & 0.51 \\
\hline 4 & 0.73 & 0.64 & 0.59 & 0.17 & 0.65 & 0.58 & 0.55 & 0.38 & 0.62 & 0.47 \\
\hline 5 & 0.72 & 0.67 & 0.73 & 0.42 & 0.64 & 0.60 & 0.65 & 0.46 & 0.62 & 0.56 \\
\hline 6 & 0.46 & 0.58 & 0.57 & 0.38 & 0.48 & 0.54 & 0.54 & $0.4 \backslash 5$ & 0.51 & 0.50 \\
\hline 7 & 0.46 & 0.80 & 0.86 & 1.00 & 0.48 & 0.72 & 0.78 & 1.00 & 0.60 & 0.89 \\
\hline 8 & 0.62 & 0.35 & 0.92 & 0.31 & 0.57 & 0.43 & 0.86 & 0.42 & 0.50 & 0.64 \\
\hline 9 & 0.34 & 0.90 & 0.78 & 0.25 & 0.43 & 0.84 & 0.70 & 0.40 & 0.64 & 0.55 \\
\hline 10 & 0.22 & 0.68 & 0.82 & 0.14 & 0.39 & 0.61 & 0.73 & 0.37 & 0.50 & 0.55 \\
\hline 11 & 0.73 & 0.47 & 0.82 & 0.28 & 0.65 & 0.48 & 0.74 & 0.41 & 0.57 & 0.58 \\
\hline 12 & 0.08 & 0.45 & 0.80 & 0.02 & 0.35 & 0.48 & 0.71 & 0.34 & 0.42 & 0.53 \\
\hline 13 & 0.31 & 0.90 & 0.00 & 0.22 & 0.42 & 0.83 & 0.33 & 0.39 & 0.63 & 0.36 \\
\hline 14 & 0.61 & 0.92 & 1.00 & 0.31 & 0.56 & 0.86 & 1.00 & 0.42 & 0.71 & 0.71 \\
\hline 15 & 0.35 & 0.90 & 0.62 & 0.18 & 0.43 & 0.84 & 0.57 & 0.38 & 0.64 & 0.48 \\
\hline 16 & 0.00 & 0.92 & 0.41 & 0.63 & 0.33 & 0.86 & 0.46 & 0.57 & 0.60 & 0.52 \\
\hline 17 & 0.67 & 0.60 & 0.79 & 0.17 & 0.60 & 0.56 & 0.71 & 0.38 & 0.58 & 0.55 \\
\hline 18 & 0.36 & 0.47 & 0.68 & 0.48 & 0.44 & 0.48 & 0.61 & 0.49 & 0.46 & 0.55 \\
\hline 19 & 0.51 & 0.90 & 0.55 & 0.05 & 0.51 & 0.83 & 0.53 & 0.35 & 0.67 & 0.44 \\
\hline 20 & 0.61 & 0.43 & 0.38 & 0.31 & 0.56 & 0.47 & 0.45 & 0.42 & 0.52 & 0.44 \\
\hline 21 & 0.62 & 0.21 & 0.81 & 0.23 & 0.57 & 0.39 & 0.73 & 0.39 & 0.48 & 0.56 \\
\hline 22 & 0.28 & 0.49 & 0.67 & 0.94 & 0.41 & 0.49 & 0.60 & 0.89 & 0.45 & 0.75 \\
\hline 23 & 0.82 & 0.00 & 0.48 & 0.00 & 0.74 & 0.33 & 0.49 & 0.33 & 0.54 & 0.41 \\
\hline 24 & 0.50 & 0.47 & 0.54 & 0.57 & 0.50 & 0.48 & 0.52 & 0.54 & 0.49 & 0.53 \\
\hline 25 & 0.11 & 0.92 & 0.42 & 0.23 & 0.36 & 0.86 & 0.46 & 0.40 & 0.61 & 0.43 \\
\hline 26 & 0.20 & 0.95 & 0.49 & 0.22 & 0.39 & 0.91 & 0.50 & 0.39 & 0.65 & 0.45 \\
\hline 27 & 0.18 & 0.94 & 0.41 & 0.21 & 0.38 & 0.89 & 0.46 & 0.39 & 0.64 & 0.43 \\
\hline
\end{tabular}

Table 6: Resulting factor effects of process parameters

\begin{tabular}{c|cccc|cccc}
\hline \multirow{2}{*}{ Level } & \multicolumn{4}{|c}{ Coconut shell based } & \multicolumn{4}{c}{ Seashell based } \\
\cline { 2 - 8 } & $\begin{array}{c}\mathrm{MP} \\
(\mathrm{MPa})\end{array}$ & $\begin{array}{c}\mathrm{MT} \\
\left({ }^{\circ} \mathrm{C}\right)\end{array}$ & $\begin{array}{c}\mathrm{CT} \\
(\mathrm{min})\end{array}$ & $\begin{array}{c}\text { HTT } \\
(\mathrm{hr})\end{array}$ & $\begin{array}{c}\text { MP } \\
(\mathrm{MPa})\end{array}$ & $\begin{array}{c}\text { MT } \\
\left({ }^{\circ} \mathrm{C}\right)\end{array}$ & $\begin{array}{c}\text { CT } \\
(\mathrm{min})\end{array}$ & HTT (hr) \\
\hline 1 & 0.5800 & 0.6700 & 0.4800 & 0.5400 & 0.5500 & 0.4400 & 0.5600 & 0.4100 \\
2 & 0.6400 & 0.6565 & 0.6200 & 0.6325 & 0.5475 & 0.5088 & 0.5038 & 0.5513 \\
3 & 0.5405 & 0.5190 & 0.5562 & 0.5419 & 0.5095 & 0.5410 & 0.4795 & 0.5324 \\
4 & 0.5812 & 0.5687 & 0.6012 & 0.5887 & 0.5388 & 0.5775 & 0.5825 & 0.5350 \\
5 & 0.4600 & 0.5200 & 0.4500 & 0.4900 & 0.5500 & 0.4400 & 0.7500 & 0.5300 \\
\hline
\end{tabular}

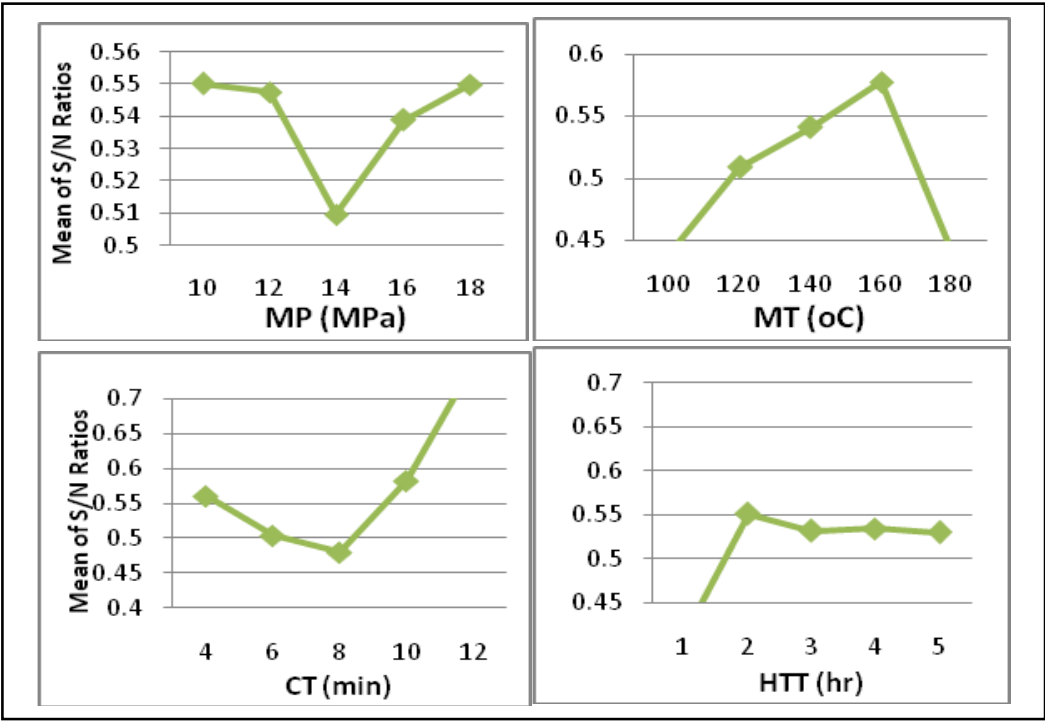

Figure 2: Main effect plots for coconut shell based sample 


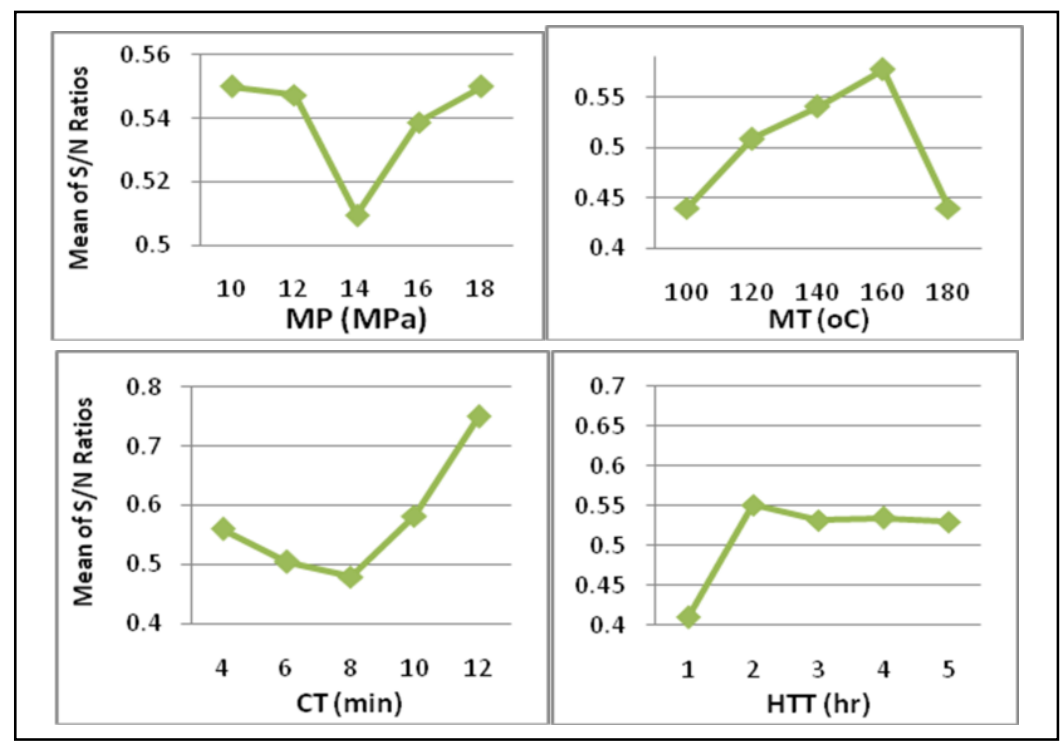

Figure 3: Main effect plots for seashell based sample

The main effect plots shown in Figure 2 indicates that optimum multi-response performance of the developed coconut shell based brake pad samples can be achieved using MP, MT and CT and HTT of $12 \mathrm{MPa}, 100^{\circ} \mathrm{C}, 6 \mathrm{mins}$ and $2 \mathrm{hrs}$ respectively while Figure 3 revealed that optimum multi-response performance of the developed seashell based brake pads can be achieved using MP, MT and CT and HTT of $10 \mathrm{MPa}, 160{ }^{\circ} \mathrm{C}, 12 \mathrm{mins}$ and $2 \mathrm{hrs}$ respectively. Any change in these optimal parameters may lead to poor bonding between the resin and its constituent fillers (Abutu et al., 2018).

\subsection{Production of optimized samples}

The optimised brake pad samples were produced using standard compression moulding process described in the earlier section. Production of the coconut shell-based sample was done using MP, MT and CT and HTT of 12MPa, $100{ }^{\circ} \mathrm{C}, 6 \mathrm{mins}$ and $2 \mathrm{hrs}$ respectively while the seashell-based sample was produced using MP, MT, CT and HTT of $10 \mathrm{MPa}, 1600^{\circ} \mathrm{C}, 12 \mathrm{mins}$ and $2 \mathrm{hrs}$ respectively as obtained from GRA. The percentage composition of the brake pad samples remains constant throughout the moulding process.

\subsection{Characterisation of optimised and commercial samples}

In order to study and compare the tribological properties of the optimised and commercial (control) brake pads, samples were characterised using the testing methods discussed in the previous section. The results of experimental findings compared with the control are summarised in Table 7. The results presented in Table 7 revealed that friction coefficient and wear rate of the commercial brake pads are 0.634 and $0.04184 \mathrm{mg} / \mathrm{m}$ respectively while that of coconut shell and seashell reinforced samples are 0.614 and $0.03156 \mathrm{mg} / \mathrm{m}$ as well as 0.542 and $0.07252 \mathrm{mg} / \mathrm{m}$ respectively. These results indicate that the coconut shell-based brake pads possesses lower wear rate compared to commercial and seashell-based samples and also falls within the category of class $\mathrm{H}(\mu>0.55)$ type of brake pads. Thus, is recommended for use in heavy duty automobile by the Society of Automobile Engineers (SAE) as reported in the work of Blau (2001) and Dagwa and Ibhadode (2006). Also, the samples reinforced with seashell falls within the class $G$ ( $1 /$ : 0.45-0.55) type of brake pads and thus suitable for use in light weight automobile. The morphology of the wear track section of the optimized and commercial sample is shown in Figure 4(a-c). The part labeled ' $A$ ' represent the wear track section of the test specimen.

As shown in Figure 4a, it can be observed that the coconut shell-based sample has the least track section with an area of $154597.2 \mu \mathrm{m}^{2}$. This is followed by commercial sample (Figure 4b) with track sectional area of $204896.1 \mu \mathrm{m}^{2}$ and finally the seashell-based sample (Figure $4 \mathrm{c}$ ) which showed the widest track section $\left(355165.0 \mu^{2}\right)$. These differences in the wear track area may be attributed to the variation in the hardness and flexural strength of the samples. This is in agreement with the earlier work of Zum-Gahr (1987) who reported that wear rate of materials are strongly dependent on the size, hardness, shape and flexibility of the abrasive particles as a results harder materials tend to have lower wear track sectional area. 


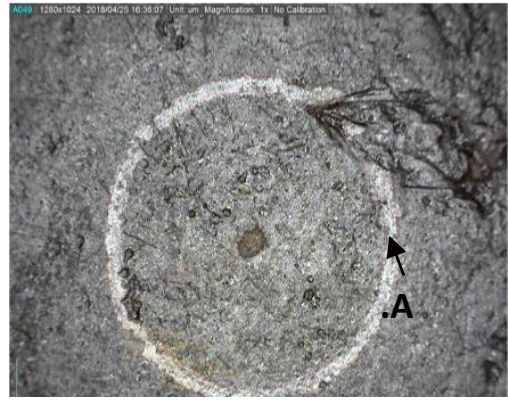

(a) Optimised coconut shell -based sample

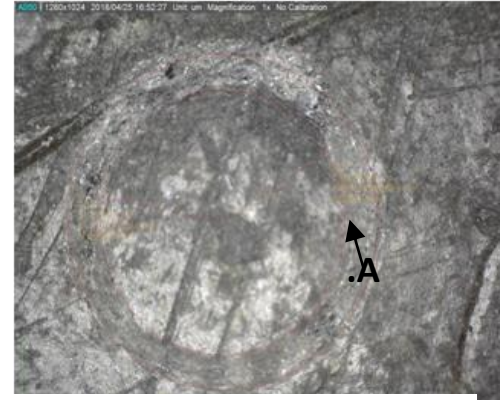

(b) Optimised seashell- based sample

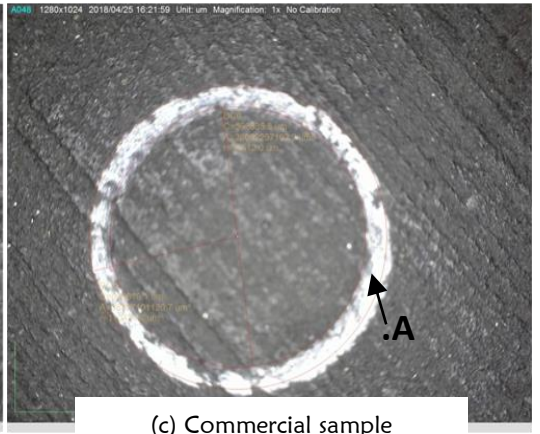

(c) Commercial sample

Figure 4: Morphology of wear track section on tribometer

Table 7: Tribological properties of optimised and control sample

\begin{tabular}{|c|c|c|c|c|}
\hline $\mathrm{S} / \mathrm{N}$ & Properties & Commercial product $(\mathrm{X})$ & Coconut shell based (C) & Seashell based $(S)$ \\
\hline 1. & Wear rate $(\mathrm{mg} / \mathrm{m})$ & 0.04184 & 0.0315 & 0.0725 \\
\hline 2. & Coefficient of friction & 0.634 & 0.614 & 0.525 \\
\hline
\end{tabular}

Table 8: ANOVA for Friction Coefficient

\begin{tabular}{l|ccccc|ccccc}
\hline Factor & \multicolumn{4}{|c|}{ Coconut shell based } & \multicolumn{5}{c}{ Seashell based } \\
\cline { 2 - 10 } & DOF & SS & MS & \multicolumn{1}{c|}{$\mathrm{F}$} & P $(\%)$ & DOF & SS & MS & F & P (\%) \\
\hline MP (MPa) & 4 & 0.0297 & 0.0074 & 9.715 & 19.388 & 4 & 0.0116 & 0.0029 & 16.422 & 24.440 \\
MT ( $\left.{ }^{\circ} \mathrm{C}\right)$ & 4 & 0.0177 & 0.0044 & 5.787 & 11.549 & 4 & 0.0142 & 0.0035 & 20.037 & 29.819 \\
CT (min) & 4 & 0.0252 & 0.0063 & 8.249 & 16.464 & 4 & 0.0117 & 0.0029 & 16.586 & 24.684 \\
HTT (hr) & 4 & 0.0729 & 0.0182 & 23.855 & 47.609 & 4 & 0.0082 & 0.0021 & 11.648 & 17.335 \\
Error & 10 & 0.0076 & 0.0008 & & 4.989 & 10 & 0.0018 & 0.0002 & & 3.721 \\
Total & 26 & 0.1532 & 0.0059 & & 100.0 & 26 & 0.0476 & 0.0018 & 100.0 \\
\hline
\end{tabular}

Table 9: ANOVA for wear rate

\begin{tabular}{|c|c|c|c|c|c|c|c|c|c|c|}
\hline \multirow{2}{*}{ Factor } & \multicolumn{5}{|c|}{ Coconut shell based } & \multicolumn{5}{|c|}{ Seashell based } \\
\hline & DOF & SS & MS & $\mathrm{F}$ & $\mathrm{P}(\%)$ & DOF & SS & MS & $\mathrm{F}$ & P (\%) \\
\hline $\mathrm{MP}(\mathrm{MPa})$ & 4 & 0.492 & 0.123 & 12.365 & 17.65 & 4 & 1.332 & 0.333 & 15.608 & 14.93 \\
\hline $\mathrm{MT}\left({ }^{\circ} \mathrm{C}\right)$ & 4 & 0.916 & 0.229 & 23.046 & 32.9 & 4 & 1.518 & 0.38 & 17.788 & 17.01 \\
\hline$C T(\min )$ & 4 & 0.603 & 0.151 & 15.169 & 21.65 & 4 & 4.93 & 1.233 & 57.755 & 55.23 \\
\hline HTT (hr) & 4 & 0.675 & 0.169 & 16.975 & 24.23 & 4 & 0.932 & 0.233 & 10.917 & 10.44 \\
\hline Error & 10 & 0.099 & 0.01 & & 3.569 & 10 & 0.213 & 0.021 & & 2.391 \\
\hline Total & 26 & 2.786 & 0.107 & & 100 & 26 & 8.926 & 0.343 & & 100 \\
\hline
\end{tabular}

\subsection{Analysis of Variance (ANOVA)}

ANOVA was conducted on the experimental responses in order to study the significant effects and percentage contribution of individual process parameters. This analysis was carried out using confidence level of $99 \%$ and significance level of $1 \%$. ANOVA table shown in Table 8-9 consist of degree of freedom (DOF), sum of square (SS), mean square (MS), $f$-value and percentage contribution (P). The ANOVA for the coefficient of friction of coconut shell-based composite shown in Table 9 indicates that HTT with percentage contribution of 47.609\% provides the greatest impact on the friction coefficient of the friction materials. This is followed by MP (19.388\%) and CT (16.464\%), finally, the least significance, MT with percentage contribution of $11.549 \%$. Also, the ANOVA for the coefficient of friction of seashell-based composite shown in Table 9 indicates that MT with percentage contribution of $29.819 \%$ provides the greatest influence on the friction coefficient of the friction materials, followed by CT (24.684\%) and MP (24.440\%) and HTT (17.335\%). In addition, the ANOVA for wear rate of coconut shell-based composite shown in Table 10 revealed that MT with percentage contribution of $32.896 \%$ provides the greatest impact on the wear rate of the friction materials, followed by HTT $(24.231 \%), C T(21.653 \%)$ and finally, MP (17.651\%). Also, the ANOVA for the wear rate of seashell-based composite shown in Table 10 showed that CT with percentage contribution of $55.232 \%$ provides the greatest impact on the wear rate of the friction materials. This is followed by MT (17.011\%), MP (14.93\%) and finally, MP (10.442\%). Also, the percentage error obtained for this analysis were less than $5 \%$ which indicate that the experimental processes were conducted with minimum influence of noise (Lawal et al., 2016; Zaharudin et al., 2011). 


\subsubsection{Empirical regression analysis}

Empirical regression equation was obtained using the experimental data with the aim of predicting the value of the investigated responses. The regression equations along with correlation coefficients (Rsq) for coconut shell and seashell based sample are shown in Equ. 7-11.

For coconut shell reinforced composite,

$\mu=1.128-0.01223$ MP - 0.000240 MT -0.01056 CT -0.0429 HTT

R-sq $=85.52 \%$ and R-sq (adj) $=75.62 \%$.

Wear rate $=0.4095-0.0011 \mathrm{MP}-0.00592 \mathrm{MT}+0.0202 \mathrm{CT}+0.0607 \mathrm{HTT}$

R-sq $=66.77 \%$ and $R$-sq (adj) $=51.63 \%$

For seashell reinforced composite,

$\mu=0.471+0.00042 \mathrm{MP}+0.000342 \mathrm{MT}-0.00050 \mathrm{CT}+0.00408 \mathrm{HTT}$

R-sq $=53.28 \%$ and R-sq (adj) $=50.11 \%$

Wear rate $=0.6536-0.0292 \mathrm{MP}+0.00570 \mathrm{MT}+0.0303 \mathrm{CT}-0.082 \mathrm{HTT}$

R-sq $=76.47 \%$ and R-sq (adj) $=63.10 \%$.

As shown in Eqn. 7-10, it can be observed that the value of R-sqadj (correlation coefficient) falls below the recommended of $80 \%$ as a result of noise which could occur from experimental uncertainty (Asuero et al., 2006).

\section{CONCLUSIONS}

This study was carried out with the aim of investigating the tribological properties of natural based (coconut shell and seashell) friction materials as a substitute for asbestos in the production of brake pads using response surface methodology and multi-response optimisation technique (GRA). From the results obtained, the following conclusion can be drawn;

i. Changes in experimental factors affects the tribological properties of the developed friction materials as all the samples produced with varying parameters gave different performance characteristics.

ii. Multi-response optimization results indicate that optimum multi-response performance of the developed coconut shell based brake pad can be achieved using MP, MT and CT and HTT of $12 \mathrm{MPa}, 100{ }^{\circ} \mathrm{C}, 6 \mathrm{mins}$ and $2 \mathrm{hrs}$ respectively while optimum multi-response performance of the developed seashell based brake pad can be achieved using MP, MT and CT and HTT of $10 \mathrm{MPa}, 160{ }^{\circ} \mathrm{C}, 12 \mathrm{mins}$ and $2 \mathrm{hrs}$ respectively,

iii. The optimized coconut shell based brake pads falls within the category of class $\mathrm{H}(\mu>0.55)$ type of brake pads while seashell based sample falls within the class $G(: 0.45-0.55)$ type of brake pads as a result can be recommended for use in heavy and light duty automobile as specified by the Society of Automobile Engineers (SAE) standards.

iv. The wear on seashell based and commercial sample showed a wider track section compared with that coconut shell which has a lower wear track section indicating a better wear resistance and friction coefficient.

$v$. Finally, the percentage errors obtained for ANOVA were less than 5\% which indicate that the experimental processes were conducted with minimum influence of noise.

\section{REFERENCES}

Abutu J., Lawal S.A., Ndaliman M.B., Lafia-Araga R.A., Adedipe O. and Choudhury I. A. (2018). Effects of process parameters on the properties of brake pad developed from seashell as reinforcement material using grey relational analysis, Engineering Science and Technology, an International Journal, 21, 787-797, Available at https://doi.org/10.1016/j.jestch.2018.05.014.

Abutu J., Lawal S.A., Ndaliman M.B., Lafia-Araga R.A., Adedipe O. and Choudhury I. A. (2019). Production and Characterization of Brake pad developed from Coconut shell reinforcement material using Central Composite Design. SN Applied Sciences. 1:18. Available at https://link.springer.com/article/10.1007/s42452-018-0084-x. Askeland, D.R. (1985). The Science and Engineering of materials. Massachusetts, PWS Publishers: U.S.A.

Asuero, A.G., Sayago, A and Gonzalez, A.G. (2006). The correlation coefficient: An Overview, Critical Reviews in Analytical Chemistry, 36, 41-59.

Bashar D., Peter, B.M. and Joseph, M. (2012). Effect of Material Selection and Production of a Cold-Worked Composite Brake Pad, Journal of Engineering of Pure and Applied Science, 2(3)48.

Blau, P.J. (2001). Compositions, Testing and Functions of Friction Brake Materials and their Additives: A report by Oak Ridge National Laboratory for U.S Dept. of Energy. Retrieved from www.Ornl.gov/webworks/cppr/y2001/rpt /11 2956.pdf.

Chin, P.F. (2003). Manufacturing process optimization for wear property of fiber-reinforced polybutylene terephthalate composites with grey relational analysis, Wear, 254, 298-306.

Dagwa, I. M., and Ibhadode, A. O. A. (2008). Some Mechanical and Physical properties of Asbestos-free Experimental brake pad. Journal of Raw Materials Research, Issue 2. Retrieved from http://www.scielo.br/scielo. php? script $=$ sci_arttextandpid $=\$ 167$ andlng $=$ enandnrm $=$ isoandtlng $=$ en . 
Dagwa, I.M., and Ibhadode, A.O. A. (2006). Some Mechanical and Physical properties of Asbestos-free Experimental brake pad. Journal of Raw Materials Research, Issue 2. Retrieved from http://www.scielo.br /scielo.php?script =sci_arttextandpid=S167858782008000200010andlng=enandnrm=isoandtIng=en.

Fono, T.R., and Koya, O.A. (2011). Palm kernel Shell in the Manufacture of Automotive Brake pad. Department of Mechanical Engineering, OAU, lle-lfe. Nigeria.

Gabriel (2016). Development of Automobile Disk Brake pad using Eco-Friendly Periwinkle Shell and Fan Palm shell materials. PhD thesis, Ahmadu Bello University, Zaria-Nigeria.

Ibhadode, A.O.A. and Dagwa, I.M. (2008). Development of asbestos-free friction pad material from palm kernel shell, Journal of the Brazilian Society of Mechanical Sciences and Engineering. 30(2), 166-173.

Ikpambese, K.K., Gundu, D.T. and Tuleu, L.T. (2014). Evaluation of palm kernel fibers (PKFs) for production of asbestos-free automotive brake pads. Journal of King Saud University - Engineering Sciences, 28 (1), 110-118.

Lawal, S.A., Ugwuoke, I.C., Abutu, J., Lafia-Araga, R.A., Dagwa, I.M. and Kariim, I. (2016). Rubber Scrap as Reinforced Material in the Production of Environmentally Friendly Brake Pad. Reference Module in Materials Science and Materials Engineering. Oxford: Elsevier; 1-10.

Mutlu, I., Eidogan, O. and Findik, F. (2009). Production of ceramic additive automotive brake pad and investigation of its braking characteristics, International journal of Tribology, 84-92.

Norton, R.L. (2001), Machine Design: An Integrated Approach, 2nd (Ed) Addison Wesley Longman, Singapore.

Roubicek, V., Raclavska, H., Juchelkova, D. and Filip, P. (2008). Wear and Environmental aspects of Composite Materials for Automotive Braking Industry. Wear, 265: 167-175.

Ruzaidi, C.M., Mustafa, A. B., Shamsul, J.B. and Alida, A.,and Kamarudin, H. (2011). Morphology and Wear Properties of Palm Ash and PCB Waste Brake Pad. International Conference on Asia Agriculture and Animal IPCBEE vol.1, IACSIT Press, Singapore.

Yawas, D.S., Aku, S.Y. and Amaren, S.G. (2016). Morphology and properties of periwinkle shell asbestos-free brake pad. Journal of King Saud University- Engineering Sciences, 28,103-109.

Zaharudin, A.M., Berhan, M.N. and Talib, R.J. (2011). The Effect of Phenolic Resin, Rubber, Calcium Carbonate and Graphite on Tribological Characteristic of Semi-Metallic Brake. AIP Conference Proceedings, 1400, (1)274. Zum-Gahr, K.H. (1987), Microstructure and Wear of Materials, Tribology Series 10, Elsevier, Amsterdam.

\author{
LIST OF ABBREVIATIONS \\ $\mathrm{DOE}=$ Design of experiment \\ $\mathrm{MP}=$ Moulding pressure \\ $\mathrm{MT}=$ Moulding temperature \\ $\mathrm{CT}=$ Curing time \\ $\mathrm{HTT}=$ Heat treatment time \\ $\mu=$ Coefficient of friction \\ $W_{\mathrm{r}}=$ Wear rate \\ $G R A=$ Grey relational analysis \\ $G R G=$ Grey relational generation \\ $G R C=$ Grey relational coefficient \\ $S / N=$ Signal to-noise ratio \\ $D_{\max }=$ maximum $G R G$ \\ $D_{\text {min }}=$ maximum $G R G$ \\ $\lambda=$ Distinguishing coefficient \\ $\rho=$ density \\ Rsq $=$ Correlation coefficient \\ ANOVA $=$ Analysis of variance \\ ROM=Rule of mixture.
}

